\title{
Electrochemical Sensor for Determination of $L$-Cysteine Based on Carbon Electrodes Modified with Ru(III) Schiff Base Complex, Carbon Nanotubes and Nafion
}

\author{
Mirha Pazalja ${ }^{1}$ Emira Kahrović ${ }^{2}$ Adnan Zahirović ${ }^{2}$, Emir Turkušić $\dot{c}^{2 *}$ \\ ${ }^{1}$ Faculty of Pharmacy, University of Sarajevo, Zmaja od Bosne 8, 71000 Sarajevo, Bosnia and \\ Herzegovina \\ ${ }^{2}$ Department of Chemistry, Faculty of Science, University of Sarajevo, Zmaja od Bosne 35, \\ 71000 Sarajevo, Bosnia and Herzegovina \\ *E-mail: turkusic@gmail.com
}

doi: $10.20964 / 2016.12 .86$

Received: 21 September 2016 / Accepted: 27 October 2016 / Published: 10 November 2016

\begin{abstract}
A new low potential electrochemical sensor for determination of $L$-cysteine based on carbon electrodes modified with $\mathrm{Ru}$ (III) Schiff base complex, multi-walled carbon nanotubes and Nafion is presented. Cyclic voltammetry, differential pulse voltammetry and flow injection analysis were employed. Measurements were carried out using Britton-Robinson buffer ( $\mathrm{pH}$ 5.50). The results showed that addition of multi-walled carbon nanotubes to $\mathrm{Ru}$ (III) complex modified glassy carbon and screen printed carbon electrodes gives increased current signals at the potential where oxidation of $L$-cysteine occurs. Flow injection amperometric measurements were performed at the operating potential $+0.15 \mathrm{~V}$ vs. $\mathrm{Ag} / \mathrm{AgCl}(3 \mathrm{M} \mathrm{KCl})$ electrode and showed fast electric current response for $L$-cysteine oxidation, demonstrating good reproducibility and stability. The sensor has a detection limit of $0.11 \mathrm{mg} \mathrm{L}^{-1}$ and a dynamic range of 50-500 $\mathrm{mg} \mathrm{L}^{-1}$. The repeatability was calculated as $2.8 \%$. New sensor was used for the determination of $L$-cysteine in pharmaceutical products.
\end{abstract}

Keywords: L-Cysteine, Ru(III) Schiff base complex, multi-wall carbon nanotubes, modified glassy carbon and screen printed carbon electrodes, voltammetric and amperometric determination

\section{$\underline{\text { FULL TEXT }}$}

(C) 2016 The Authors. Published by ESG (www.electrochemsci.org). This article is an open access article distributed under the terms and conditions of the Creative Commons Attribution license (http://creativecommons.org/licenses/by/4.0/). 